\title{
Yield, Agronomic Characteristics and Chemical Composition of Silage Fodder (Sorghum bicolor L.) With and Without Fertilization
}

\begin{abstract}
Analco-Cisneros, Gerardo; Maldonado-Peralta, María de los Á. ${ }^{2}$; Sánchez-Santillán, Paulino²; Bottini-Luzardo, María B. ${ }^{2}$; Valenzuela-Lagarda, José L. ${ }^{3}$; Rojas-García, Adelaido R. ${ }^{2 *}$

1Universidad Autónoma de Guerrero, Maestría de Producción de Bovinos en el Trópico. Cuajinicuilapa, Guerrero, México. ${ }^{2}$ Universidad Autónoma de Guerrero, Facultad de Medicina Veterinaria y Zootecnia No 2, Cuajinicuilapa, Guerrero, México. ${ }^{3}$ Universidad Autónoma de Guerrero, Centro Regional de Educación Superior de la Costa Chica, Cruz Grande, Guerrero, México
\end{abstract}

*Corresponding Author: rogarcia@uagro.mx

\begin{abstract}
Objective: To evaluate the yield and structural characteristics of sorghum fodder, as well as the chemical quality of the fodder and the silage with and without fertilization.

Design/Methodology/Approach: The evaluated variables were, in the fodder: dry matter yield (DMY, kg ha ${ }^{-1}$ ), leaf:stalk ratio $\left(L: S, g^{-1}\right)$, plant height $(H, c m)$ and intercepted radiation $(I R, \%)$; and in the silage: dry matter (DM, \%) crude protein $(C P, \%)$, neutral detergent fiber (NDF, \%), acid detergent fiber (ADF, \%), lactic acid (LA, \%) and pH. There were two treatments, with fertilization and without fertilization.

Results: The agronomic characteristics L:S, H and IR improved with fertilization $(P<0.05)$. The DMY with fertilization was $7060 \mathrm{~kg} \mathrm{DM} \mathrm{ha}^{-1}$ and without fertilization, it was $5472 \mathrm{~kg} \mathrm{DM} \mathrm{ha}^{-1}$. The values of DM, CP, NDF, ADF and LA of the silage with fertilization were 33.60, 7.83, 51.06, 28.51 and 4.51\%, respectively, and the $\mathrm{pH}$ was 4.3, and without fertilization these values were $47.67,5.83,43.36,25.21$ and $2.86 \%$, respectively, and the $\mathrm{pH}$ was 4.66; all values were different when comparing with and without fertilization $(P<0.05)$
\end{abstract}

Study Limitations/Implications: These quality parameters should continue to be studied in sorghum silages and with different fertilization doses to expand the decision outlook.

Findings/Conclusions: According to the results obtained, it is concluded that the sorghum fodder crop should be fertilized for the ensilage, since higher dry matter yield, better agronomic, and nutritional characteristics are obtained.

Keywords: sorghum, sowing, fertilization, ensilage, bromatology analysis.

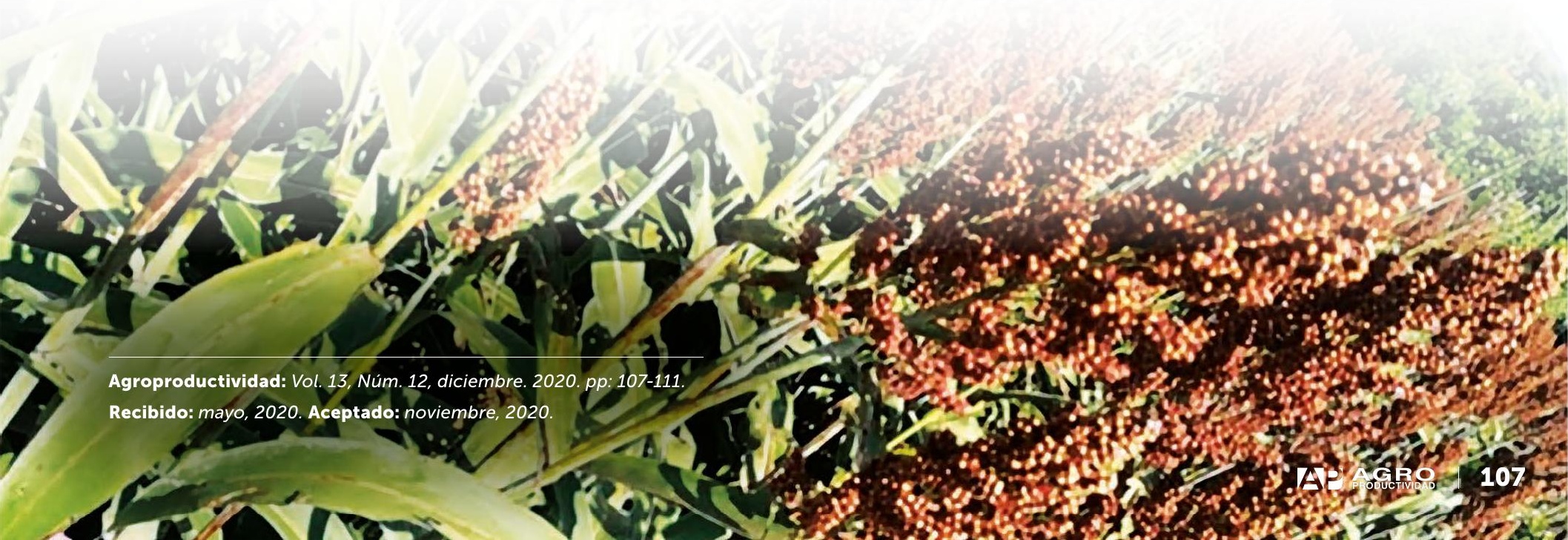




\section{INTRODUCTION}

SORดीUח $\begin{aligned} & \text { fodder is very important } \\ & \text { in the elaboration of }\end{aligned}$ balanced feed for animals (Nichols et al., 1997). It is of forage quality and requires less water than maize, so it adapts to rainfed management. In addition, it can be cultivated in the tropics with productive response and nutritional value similar to maize (Contreras et al., 2011; Rebora et al., 2018).

Sorghum fodder uses less water than maize in grain production, in addition to its dense and ramified roots, and the lower growth speed of the leaf area, making the use of nitrogen of the soil more efficient (Bolaños et al., 2018) al emplear plantas con concentraciones promedio de $300 \mathrm{~g} \mathrm{~kg}^{-1}$ de MS. Se estudiaron tres variedades de grano (Solarius, Aralba y Topsilo. Nitrogen is the most restrictive element for plant growth and therefore for production (Diez, 2015). In recent decades its use has increased to raise the productivity of the crops (Espinosa et al., 2002).

It is important to understand the yield and nutritional composition of sorghum since it is an alternative in the Mexican tropics due to the irregularity of rainfall (Rojas et al., 2018). This irregularity leads to times of scarcity and abundance of fodder. In times of abundance, the excess fodder must be turned into silage to be used in times of scarcity. Ensilage is a fodder conservation method with high moisture content (60-70\%). This method consists in compaction of the fodder, air expulsion and fermentation, which allow bacterial acidification of the silage until obtaining $\mathrm{pH}$ values below 5 (Fernández et al., 2017)

In Mexico, Ramírez et al. (2019) obtained in average $27.7 \%$ of dry matter and $11500 \mathrm{~kg} \mathrm{MS} \mathrm{ha}^{-1}$ with different varieties of sorghum in the tropics, at the time of ensilage and in the silage $\mathrm{pH}$ values of 3.7 and raw protein of $8.4 \%$. However, there are few studies about the effect of fertilization on the quality of sorghum silages in Mexico. Therefore, the objective of this study was to evaluate the yield and the chemical quality of the fodder and the silage, with and without fertilization

\section{MATERIALS AND METHODS Location}

The field research was carried out in 2018 in Rancho los Laureles, located on $\mathrm{km} 7$ of the
Cuajinicuilapa highway, Guerrero-Santo Domingo, Oaxaca, and the chemical studies were done in the Animal Nutrition Laboratory of the Veterinary and Zootechnics School No. 2 of the Universidad Autónoma de Guerrero, on Km 197 of the AcapulcoPinotepa Nacional highway, in Cuajinicuilapa, Guerrero, Mexico; coordinates $16^{\circ} 08^{\prime} \mathrm{N}$ and 98 23' W 50 masl, average temperature $29^{\circ} \mathrm{C}$ and accumulated rainfall of $1200 \mathrm{~mm}$.

The climate is Aw, dry tropical according to the KöppenGeiger classification (García, 2004). The climate data were obtained from CONAGUA's agro-meteorological station located in the municipality of Cuajinicuilapa, $10 \mathrm{~km}$ from the experimental plots. The maximum temperature, $36{ }^{\circ} \mathrm{C}$, was reached on the month of November, while the minimum, $17{ }^{\circ} \mathrm{C}$, in August and September; the accumulated rainfall was $950 \mathrm{~mm}$ (Table 1)

\section{Management of the Plots}

Sowing was carried out in the rainy season, on August $1^{\text {st }}$, and the ensilage on November $1^{\text {st }}, 2018$, in Rancho los Laureles, using sorghum from the company DEKALB ${ }^{\circledR}$ variety BRS-72. Six hectares of sorghum were sown; three of them fertilized and three without fertilization. Sowing was carried out with an agricultural tractor (New Holland ${ }^{\circledR}$, Mexico) in furrows of 80 centimeters of separation, placing the seed by continuous string and at a depth of $3 \mathrm{~cm}$; at 14-16 seeds per linear meter, the sowing density was $8 \mathrm{~kg} \mathrm{ha}^{-1}$ of pure viable seed. The soil, of clay-sandy texture, pH 4.8 to 5.0, was deficient in organic matter.

At the time of sowing, $150 \mathrm{~kg} \mathrm{ha}^{-1}$ of DAP fertilizer (1846-00) and $100 \mathrm{~kg} \mathrm{ha}^{-1}$ of ammonium sulfate (12-61-00) were applied for the treatment with fertilization, together with the seed with the sower's hopper. At 40 days after sowing (das), fertilization was carried out again with 150 $\mathrm{kg} \mathrm{ha}^{-1}$ of urea (46-00-00). Weed control was performed manually with a hoe.

Table 1. Maximum, minimum, mean $\left({ }^{\circ} \mathrm{C}\right)$ temperature and precipitation $(\mathrm{mm})$ during the study period in 2018

\begin{tabular}{l|l|l|l|l|l|} 
Month & Maximum & Minimum & Average & Precipitation & Irrigation
\end{tabular}

\begin{tabular}{l|l|l|l|l|l} 
August & 33 & 17 & 25 & 269 & No \\
\hline September & 33 & 17 & 25 & 290 & No \\
\hline Octuber & 35 & 18 & 26 & 282 & No \\
\hline November & 36 & 18 & 27 & 109 & No
\end{tabular}


At 90 das, fodder cutting was performed with an agricultural tractor (New Holland ${ }^{\circledR}$, Mexico) and the ensilage with a silo (Twin $623600^{\circledR}$, SWISSMEX). The fodder chopping was in 2 to $3 \mathrm{~cm}$, depositing it directly in trailers to be transported to the silo (cake) that was uncovered after 90 days (180 das).

\section{Evaluated Variables}

\section{Dry Matter Yield}

At 90 days after sowing (das), the plants were ensilaged in the milky-pasty stage of panicle. One day later two squares of $1 \mathrm{~m}^{2}$ per ha ${ }^{-1}$ were harvested at $10 \mathrm{~cm}$ height from the ground. The harvested fodder was washed and placed in paper bags. The samples were dried in a forced-air stove at $55{ }^{\circ} \mathrm{C}$ until constant weight, and their weight was recorded.

\section{Plant Height}

Twenty readings per repetition were taken randomly one day before harvesting the fodder for ensilage. For this purpose, a ruler measuring in $\mathrm{cm}$ was used, which

\section{Statistical Analysis}

The treatments were assigned to experimental units according to a design of random blocks with three repetitions, and each repetition was one ha ${ }^{-1}$. The data obtained were organized and analyzed with PROC GLM of SAS (SAS, 2011), the means were compared with Tukey's test $(P<0.05)$.

The experimental unit for the yield was a sample taken from each one of the two squares, from each one of the three hectares with and without fertilization; in total, six experimental units with fertilization and six without fertilization.

\section{RESULTS AND DISCUSSION}

The fodder yield with fertilization was $7060 \mathrm{~kg} \mathrm{MS} \mathrm{ha}^{-1}$ and without fertilization $5472 \mathrm{~kg} \mathrm{MS} \mathrm{ha}^{-1}(\mathrm{P}<0.05)$. The plant height, leaf:stalk ratio, and intercepted radiation were also higher with fertilization $(P<0.05)$ than without fertilization, $1.77 \mathrm{~cm}, 0.44 \mathrm{~g} \mathrm{~g}^{-1}$ and $95 \%$ vs. $1.62 \mathrm{~cm}$, $0.37 \mathrm{~g} \mathrm{~g}^{-1}$ and $89 \%$, respectively.

was placed randomly in the plots so that the lower part of the ruler was at ground level and the posterior part was in contact with the flag leaf.

\section{Leaf:Stalk Ratio}

After harvesting the fodder for ensilage, the weights of the leaves and stalks of the plants were

\begin{tabular}{|c|c|c|c|}
\hline Variable & $\begin{array}{c}\text { With } \\
\text { fertilization }\end{array}$ & $\begin{array}{c}\text { No } \\
\text { fertilization }\end{array}$ & SEM \\
\hline $\mathrm{DM} \mathrm{kg} \mathrm{ha}^{-1}$ & $7060 a$ & $5472 b$ & 110 \\
\hline Height $(\mathrm{cm})$ & $1.77 a$ & $1.62 b$ & 0.42 \\
\hline Leaf: stem ratio $\left(\mathrm{g} \mathrm{g}^{-1}\right)$ & $0.44 a$ & $0.37 b$ & 0.05 \\
\hline Intercepted radiation (\%) & $95 a$ & $89 b$ & 0.12 \\
\hline
\end{tabular}

ab Means with different literals in the same row are statistically different $(p<0.05), D M=$ dry matter yield; $S E M=$ standard error of the mean recorded in dry base and with them the leaf:stalk ratio was estimated $\left(\mathrm{g} \mathrm{g}^{-1}\right)$. Drying was done at $55^{\circ} \mathrm{C}$ until constant weight in a forced air stove.

\section{Intercepted Radiation}

Five radiation readings per experimental plot were taken randomly the day prior to the harvest, with the method of wooden meter described by Rojas et al. (2016).

\section{Chemical Variables}

In the plant components, when finalizing the ensilage process which lasted 90 days, the following variables were determined in the ensilage: dry matter (DM), crude protein (CP), neutral detergent fiber (NDF), acid detergent fiber (ADF), lactic acid (LA), and pH (Van Soest et al., 1991; AOAC, 2005). Three samples were taken randomly in the middle part of each ensilage.
Boschini and Elizondo (2005), when evaluating different cutting ages in sorghum fodder, obtained in average 6303 $\mathrm{kg} \mathrm{MS} \mathrm{ha}{ }^{-1}$ that are very similar to results in this study. On the other hand, Ibarguren et al. (2020) reported in sorghum hybrids a height that ranges from 1.54 to 2.81 by applying fertilization (18-4600), similar to results in this study. Espinosa et al. (2002) reported in sorghum at different physiological ages that height and yield increase from nitrogenous fertilization. Diez (2015) reported a higher amount of leaf and panicle, up to $20 \%$, when nitrogenous fertilization is carried out in sorghum crop destined to ensilage. The height and intercepted radiation are important for a good harvest in the milky-pasty stage of the panicle; in tropical fodders, 95\% of intercepted radiation is considered optimal and it is reached with fertilization (Da Silva and Nascimento, 2007; Rojas et al., 2018).

There was a difference in the DM obtaining a higher percentage from the sorghum plant fertilized with $37.66 \%$ and a lower one in non-fertilized sorghum of $33.60 \%(P<0.05)$. In the CP of the panicle, stalk and leaf 
of the sorghum plant there were differences between the fertilized and non-fertilized sorghum, obtaining the highest percentage when fertilized with 2.49, 4.89 and $15.72 \%$ of protein $(P<0.05)$. The neutral detergent and acid detergent fibers in the components of the sorghum plant are quite variable depending on whether it is fertilized or not.

For their part, Boschini and Elizondo (2005) obtained a similar behavior to this study's when evaluating different frequencies of black sorghum fodder in the structures of the plant obtained in average, harvesting sorghum at 133 days after sowing, dry matter of $23.3 \%$, crude protein of $13.88 \%$, and neutral and acid detergent fiber with 70.39 and $38.32 \%$, respectively, in the leaf's component In contrast, in the stalk the crude protein content was lower, with $4.79 \%$, although higher in the neutral and acid detergent fibers with 80.91 and 53.28 , respectively. However, in this study it was harvested 90 days after sowing since it is when the best conditions were found for ensilage with the panicle in milky-pasty stage; this depends on the variety and soil-climate elements of the region (Ibarguren et al., 2019).

Compared to silage without fertilization, the sorghum silage with fertilization produced higher values $(P<0.05)$ of CP, NDF, ADF and LA (7.83, 51.06, 28.51 and 4.51\%, respectively) and lower value $(\mathrm{P}<0.05)$ of $\mathrm{pH}(4.3)$. The

Table 3. Nutritional analysis of the components of sorghum plants with and without fertilization for ensilage.

\section{With fertilization Nortilization}

SEM

\begin{tabular}{l|c|c|c}
\hline DM & $33.60 b$ & $37.66 a$ & 3.19 \\
\hline PCP & $2.49 a$ & $1.68 b$ & 0.25 \\
\hline PCT & $4.89 a$ & $3.11 b$ & 0.52 \\
\hline PCH & $15.72 a$ & $14.48 b$ & 0.60 \\
\hline FDNP & $85.01 b$ & $89.08 a$ & 1.87 \\
\hline FDNT & $61.74 b$ & $71.31 a$ & 2.19 \\
\hline FDNH & $61.55 b$ & $67.50 a$ & 1.39 \\
\hline FDAP & $21.54 b$ & $24.55 a$ & 2.33 \\
\hline FDAT & $39.19 b$ & $44.53 a$ & 1.30 \\
\hline FDAH & $33.77 a$ & $33.76 a$ & 0.53
\end{tabular}

$a b$, means with different literals in the same row are statistically different $(p<0.05)$; SEM = standard error of the mean; $D M=$ dry matter of the plant; $\mathrm{PCP}=$ crude panicle protein; $\mathrm{PCT}=$ crude stem protein; $\mathrm{PCH}=$ crude leaf protein; FDNP = neutral detergent fiber of panicle; $F D N T=$ stem neutral detergent fiber; $F D N H=$ neutral detergent fiber of the leaf; FDAP = acid detergent fiber of the panicle; FDAT = acid detergent fiber from the stem; FDAH = neutral detergent fiber of the leaf.
Table 4. Chemical analysis of the sorghum silage with and without fertilization.

With fertilization No fertilization

SEM

\begin{tabular}{l|c|c|c}
\hline DM & $33.60 b$ & $47.67 a$ & 3.19 \\
\hline PC & $7.83 a$ & $5.83 b$ & 0.64 \\
\hline FDN & $51.06 a$ & $43.36 b$ & 1.87 \\
\hline FDA & $28.51 a$ & $25.21 b$ & 0.84 \\
\hline AL & $4.51 a$ & $2.86 b$ & 0.37 \\
\hline pH & $4.3 b$ & $4.66 a$ & 0.08
\end{tabular}

ab Means with different literals in the same row are statistically different $(p<0.05)$; $D M=$ dry matter; $P C=$ crude protein; NDF $=$ neutral detergent fiber; FDA = acid detergent fiber; $A L=$ lactic acid; $\mathrm{pH}=$ hydrogen potential; SEM = standard error of the mean.

advantage of the sorghum silage without fertilization was its higher DM (47.67\%), which in the fertilized sorghum silage was $33.60 \%$. These results were similar to those reported by Corral et al. (2011) who reported higher values of CP and LA from nitrogenous fertilization.

Dávila et al. (2016), when evaluating sorghum silages associated with Tithonia diversifolia, found similar values of DM $(27 \%)$ to those of this study, and higher of CP (13.26\%); this higher value of CP is probably due to the association of sorghum with $T$. diversifolia.

\section{CONCLUSIONS}

The sorghum fodder crop should be fertilized to ensile since higher yield of dry matter, and better agronomic and chemical characteristics are obtained. It is suggested to perform studies with ensilages with more varieties of sorghum, other levels of fertilization, other frequencies of cutting, and associations with other species.

\section{REFERENCES}

AOAC. (2005). Official Methods of Analysis. Edition 18. Association of Official Analytical Chemists. Washington, EE.UU. 1928 p.

Bolaños, A.E.D., Claude, E.J. \& Audebert, G. (2018). Rendimiento y calidad de híbridos de sorgo con y sin nervadura café. Revista Mexicana de Ciencias Agrícolas, 3(3), 441-449.

Boschini, F.C. \& Elizondo, S.J. (2005). Determinación de la calidad y la producción de sorgo negro forrajero (Sorghum almum) en edades para ensilar. Agronomía mesoamericana, 16(1), 29-36.

Contreras, G.F., Marsalis, M., Angadi, S., Smith, G., Lauriault, L.M. \& VanLeeuwen, D. (2011). Fermentability and Nutritive Value of Corn and Forage Sorghum Silage When in Mixture with Lablab Bean. Crop Science, 51, 1307-1313

Corral, L.A., Domínguez, D.D., Rodríguez, A.F.A., Villalobos, V.G., Ortega, G.J. A. \& Muro, R.A. (2011). Composición química y cinética de degradabilidad de ensilaje de maíz convencional y sorgo de nervadura café. Revista Brasileira de Ciencias Agrarias, 6(1), 181-187. 
Da Silva, S.C. \& Nascimento, J.D.D. (2007). Avanços na pesquisa com plantas forrageiras tropicais em pastagens: características morfofisiológicas e manejo do pastejo. Revista Brasileira de Zootecnia, 36, 122-138.

Dávila, H.A., Lepe, L.M., Polanco, E., Saavedra, C. \& Guerra, C.D. (2016). Determinación del valor nutricional y evaluación sensorial del ensilado de Sorghum vulgare y Tithonia diversifolia. REDVET Rev. Electrón. Vet., 17(10), 1-11.

Diez, M. (2015). Fertilización nitrogenada en sorgo doble propósito con destino a silaje. Memoria tecnica. INTA. 7-8 p.

Espinosa, F.J., Carrillo, A.J., Palma, L.D.J., Peña, C.J.J. \& Salgado, G.S. (2002). Efficiency of Nitrogen Fertilization in Sorghum Using the 15 N. Isotope Technique, 20(2), 129-139.

Fernández, P.M.E., Zambrano, S.S.J., Zumba, M.L.C. \& López, C.G. (2017). Consideraciones generales sobre el proceso de elaboración de silos. Revista Científico - Educacional de La Provincia Granma, 13(3), 107-116.

García, E. (2004). Modificaciones al sistema de clasificación climática de Koppen. 4ed. Universidad Nacional Autónoma de México. México, D. F. 217 p.

Ibarguren, L., Rebora, C., Bertona, A. \& Antinini, C. (2020). Sorghum silage production in the northern oasis of Mendoza, Argentina. Revista de la Facultad de UNCUYO, 52(1), 121-127.

Nichols, S.W., Froetschel, M.A., Amos, H.E. \& Ely, L.O. (1997). Effects of Fiber from Tropical Corn and Forage Sorghum Silages on Intake, Digestion, and Performance of Lactating Dairy Cows. Journal Dairy Science, 81, 2383-2393

Ramírez, O.S., Meza, V.V.M., Trejo, C.A., Hernández, B.J. \& Villalobos, V.G. (2019). Chemical composition and in situ ruminal disappearance of sorghum silages grown in the mexican humid tropic. Revista de la Facultad de UNCUYO, 51(2), 353-366

Rebora, C., Ibarguren, L., Barros, A., Bertona, A., Antonini, C., Arenas, F., Calderón, M. \& Guerrero, D. (2018). Corn silage production in the northern oasis of Mendoza, Argentina. Revista de la Facultad de UNCUYO, 50(2), 369-375.

Rojas, G.A.R., Torres, S.N., Maldonado, P.M.A., Sánchez, S.P., García, B.A., Mendoza, P.S.I., Álvarez, V.P. \& Hernández, G.A. (2018). Curva de crecimiento y calidad del pasto cobra (Brachiaria HIBRIDO BR02/1794), a dos intensidades de corte. Agroproductividad, 11(5), 34-38.

Rojas, G.A.R., Hernández, G.A., Quero, C.A.R., Guerrero, R.J.D., Ayala, W, Zaragoza, R.J.L. \& Trejo, L.C. (2016). Persistencia de Dactylis glomerata L. solo y asociado con Lolium perenne L. y Trifolium repens L. Revista Mexicana de Ciencias Agrícolas, 7(4), 885-895

SAS. (Statistical Analisys System). (2011). SAS Proceeding Guide, Version 9.0 SAS Insitute. Cary NC. USA.

Van Soest, P.J., Robertson, J.B. \& Lewis, B.A. 1991. Methods for dietary fiber, neutral detergent fiber, and nonstarch polysaccharides in relation to animal nutrition. Journal of Dairy Science, 74, 3583-3597.

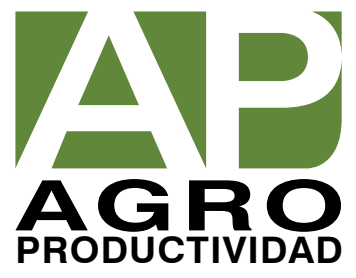

